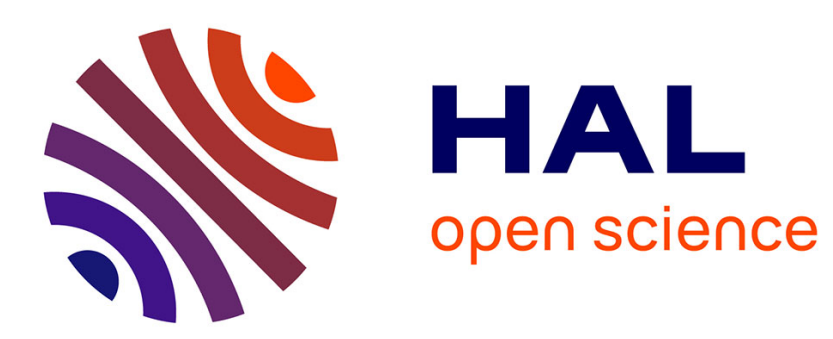

\title{
Purepecha, a Polysynthetic but Predominantly Dependent-Marking Language
}

Claudine Chamoreau

\section{To cite this version:}

Claudine Chamoreau. Purepecha, a Polysynthetic but Predominantly Dependent-Marking Language . Handbook of Polysynthesis. , 2017, 10.1093/oxfordhb/9780199683208.013.38 . halshs-01683138

\section{HAL Id: halshs-01683138 \\ https://shs.hal.science/halshs-01683138}

Submitted on 12 Jan 2018

HAL is a multi-disciplinary open access archive for the deposit and dissemination of scientific research documents, whether they are published or not. The documents may come from teaching and research institutions in France or abroad, or from public or private research centers.
L'archive ouverte pluridisciplinaire HAL, est destinée au dépôt et à la diffusion de documents scientifiques de niveau recherche, publiés ou non, émanant des établissements d'enseignement et de recherche français ou étrangers, des laboratoires publics ou privés. 
Chamoreau, Claudine. 2017. Purepecha: A polysynthetic but predominantly dependent-marking language. M. Fortescue, M. Mithun, \& N. Evans (eds). Handbook of Polysynthesis.

Oxford : Oxford University Press. 667-695

\title{
Oxford Handbooks Online
}

\section{Purepecha, a Polysynthetic but Predominantly Dependent-Marking Language a}

\author{
Claudine Chamoreau
}

The Oxford Handbook of Polysynthesis

Edited by Michael Fortescue, Marianne Mithun, and Nicholas Evans

Print Publication Date: Sep 2017 Subject: Linguistics, Morphology and Syntax

Online Publication Date: Nov 2017 DOI: 10.1093/oxfordhb/9780199683208.013.38

\section{Abstract and Keywords}

Purepecha (language isolate, Mexico) has one relevant characteristic that leads to identifying it as a polysynthetic language: productive verbal morphology (in particular locative suffixes). Purepecha is a predominantly dependent-marking language, as its pronominal markers are enclitics, generally second position enclitics. But, in some contexts Purepecha shows head-marking characteristics. Today, pronominal enclitics exhibit variation, tending to move to the rightmost position in the clause; they may encliticize to the predicate itself, showing a head-attraction or polypersonalism strategy and making Purepecha more polysynthetic. But this language lacks noun incorporation. Purepecha has three types of non-finite clause: two subordinate clauses (non-finite complement clauses and purpose clauses) and a syntactically independent clause (the chain-medial clause). This seemingly inconsistent situation (characterized by a correlation of different properties, some of which have not been identified as polysynthetic) calls for addressing the typological classification of Purepecha among the polysynthetic languages.

Keywords: Purepecha, locative suffixes, dependent marking, head attraction, head marking, pronominal enclitics, non-finite clause 


\subsection{Introduction}

FORTESCUE (1994) lists various traits that tend to cluster together to give rise to a polysynthetic language, but says that they are not necessarily all attested in a single language. These include noun incorporation, a large inventory of bound morphemes, numerous morphological slots, the verb constituting a clause, head marking, pronominal markers on verbs, and adverbial elements integrated into verbs. In the same framework, Evans and Sasse (2002) propose a definition that reflects the correlation of different typological features and the possibility that languages without incorporation and pronominal markers on verbs can also be considered polysynthetic. They claim that

Essentially, then, a prototypical polysynthetic language is one in which it is possible, in a single word, to use processes of morphological composition to encode information about both the predicate and all its arguments, for all major clause types to a level of specificity, allowing this word to serve alone as a freestanding utterance without reliance on context. (2002: 3)

Mithun (2009: 15) gave emphasis to the correlation of various features and noted that etymologically, the term 'polysynthesis' refers simply to multiple morphemes per word, but it remains to be seen what other properties might be crucial for predicting additional characteristics. From a different and restrictive perspective, according to Baker (1996: 19), polysynthesis is defined by noun incorporation and verb agreement. Taking account of these perspectives is relevant to characterizing the correlation of properties that lead us to identify a polysynthetic language and to defining the limits within which a specific language must (p. 668) fall in order to be polysynthetic. This leads us to ask how far a specific language is polysynthetic: the goal of this chapter is to apply this question to the case of Purepecha.

The structure of Purepecha demonstrates that the fundamental features typically associated with polysynthesis - that is, elaborate verbal morphology, holophrasis, head marking, and noun incorporation-do not need to coexist. Purepecha is characterized by the first two, as illustrated in (1a). In particular, Purepecha has a large inventory of locative suffixes, various suffixes for voice changes, and a third person plural object suffix. But, in contrast with this productivity, Purepecha has less-developed directional, desiderative, and adverbial suffixes. The presence of various types of suffixes constitutes a significant characteristic that allows the building of holophrasis, as illustrated in (1a). Various characteristics of the derivational suffixes lead us to argue that they are lexical suffixes and not possible traces of noun incorporation. Purepecha is predominantly a dependent-marking language, as its pronominal markers are enclitics, generally second position enclitics, as illustrated in (1b). 


\section{Purepecha, a Polysynthetic but Predominantly Dependent-Marking Language}

a. ata-mu-ku-ncha-nt'a-x-p-ka=ri

beat-ORIF-NCS-DES-IT-AOR-PST-ASS1/2S=S2SG

'You had wanted to hit the mouth of another again.'

(1)
b. no=ri
xïpa-ku-a-xa-p-ka
$\mathrm{NEG}=\mathrm{S} 2 \mathrm{SG}$
steal-APPL3O-O3PL-PROG-PST-ASs1/2S
'You were not stealing from them.'

In three contexts, Purepecha shows head marking. In the first, the head marking is the consequence of the form of the pronouns: the third person singular is always unmarked, and the first person singular is unmarked when it appears with the assertive mood (that has the form $-k a$ for speech act participants, codified as $1 / 2)$, as illustrated in (2a). In the second context, the third person plural object marker is a verbal suffix that only occurs in the verb (2a). In the third context, the applicative suffix encodes a recipient or the possessor of the entity introduced as the object (external possession); this suffix appears exclusively within the verb, as in (2b). Moreover, pronominal enclitics display the development of a head-attraction strategy in which they tend to move to the rightmost position in the clause and may encliticize to the predicate itself.

a. che-ra-a-xïn-ka

$$
\begin{aligned}
& \text { be_afraid-CAUS-O3PL-HAB-ASs1/2s } \\
& \text { 'I scare them.' }
\end{aligned}
$$

(2)
b. jwa-chi-s-ti=rini
bring-APPL1/2O-AOR-ASS3S=O1SG
'He brought it to me.' 'He brought something mine to me.'

Next, Purepecha entirely lacks the fourth feature, that is, noun incorporation. Lastly, Purepecha has developed the use of non-finite clauses in three contexts: two subordinate clauses (non-finite complement clauses and purpose clauses) and a syntactically independent clause (the chain-medial clause). In these three contexts, the verb may be marked by (p. 669) the third person plural object suffix - $a$, and in one, the chain-medial clause, the pronominal enclitics may be attached to the verb. Because of this seemingly inconsistent situation, Baker would exclude Purepecha as a polysynthetic language, as it lacks noun incorporation and head marking, the two prototypical criteria in his view. But as defined by Fortescue, Evans and Sasse, or Mithun, Purepecha is polysynthetic. However, the correlation of these properties, some of which have not been identified as polysynthetic, calls for addressing the typological classification of Purepecha among the polysynthetic languages. Exploring the sentential vs. non-sentential typology proposed by Drossard (1997: 252), I will argue that Purepecha is a polysynthetic language located 


\section{Purepecha, a Polysynthetic but Predominantly Dependent-Marking Language}

somewhere in between the sentential and non-sentential types, with tendencies toward the sentential type.

The chapter is organized as follows. In Section 32.2, I briefly sketch the basic typological characteristics of Purepecha. In Section 32.3, I discuss the predominantly dependentmarking characteristics of Purepecha (32.3.1), showing contexts that reveal headmarking constructions (32.3.2) and head attraction (32.3.3). In Section 32.4 I illustrate its elaborate verbal morphology, contrasting the large inventory of locative suffixes (32.4.1) and the less developed inventory of other types of suffixes (32.4.2). In Section 32.5, I describe three types of non-finite clause in Purepecha. Finally, in Section 32.6, I review the different characteristics described in this chapter and assess to what extent Purepecha is polysynthetic, taking into account especially the sentential vs. nonsentential typology proposed by Drossard (1997: 252).

\subsection{Basic Typological Characteristics of Purepecha}

Purepecha (formerly known as Tarascan) is classified as a language isolate and is spoken in the state of Michoacán in western Mexico by approximately 110,000 people (Chamoreau 2009, 2012). The classification of Purepecha as a part of the Mesoamerican linguistic area is still debated, but generally it is not classified as a Mesoamerican language, as it shows very few signature Mesoamerican characteristics (Smith-Stark 1994).

Purepecha has nominative-accusative alignment, and is a case-marking language in which the nominal subject has no overt marker. The object is generally marked by the objective case marker -ni. This morpheme encodes the object of a transitive verb, such as misitu-ni 'the cat' in (3), and both objects of a ditransitive verb, such as inte-ni wantantskwa-ni and Puki-ni, in (4). The presence or absence of the object case marker depends on different hierarchies: (i) the inherent semantic properties of the referent (human, animate); (ii) properties related to grammatical features (definite, count noun vs. mass noun, generic vs. specific, etc.); and (iii) pragmatic strategies (topic, focus) (Chamoreau 2009). The presence of the objective case marker -ni generally indicates that the noun phrase is characterized as individuated.
jo celia
ata-x-ti
ima-eri
misitu-ni
(3) yes Celia
beat-AOR-Ass3s
DEM-GEN
cat-oBJ
Yes, Celia beat her cat.'

(p. 670) 


\section{Purepecha, a Polysynthetic but Predominantly Dependent-Marking Language}

(4)

\begin{tabular}{|c|c|c|c|}
\hline arhi-x-ti & inte-ni & wantantskwa-ni & Puki-ni \\
\hline tell-AOR-Ass3s & DEM-OBJ & story-oBJ & Puki-овJ \\
\hline
\end{tabular}

A ditransitive verb in Purepecha is mixed or hybrid in type (Chamoreau 2008). According to criteria proposed in Malchukov et al. (2010), it exhibits neutral alignment for flagging, that is, the objective case marker $-n i$ is the same for the patient of a transitive verb and the patient and the recipient of a ditransitive verb, as illustrated in (3) and (4), and for syntactic processes such as topicality, focus, interclausal co-reference control, and relativization. But Purepecha displays secundative alignment for accessibility to voice change: in other words, the recipient of the ditransitive verb aligns with the object of the transitive verb in reflexive, reciprocal, passive, and antipassive constructions, as shown in (5a) for the passive construction. Example (5b) is ungrammatical because the patient of the ditransitive verb cannot become the subject of the passive construction.

(5)
a. tataka-icha arhi-na-xa-ti=kxï
wantantskwa
thaletskwa-icha
boy-PL
say-PAS-PROG-ASS3S=S3PL
story
elf-PL-GEN
'The boys are being told the story about the elves.'

\section{b. ${ }^{*}$ wantantskwa thaletskwa-icha-iri arhi-na-xa-ti tataka-icha-ni}

Purepecha displays the predominance of dependent marking, for example with the pronominal enclitic, as in (1b), and the genitive suffix, as illustrated in (6) and (7).

jinte-s-ti wámpa Maria-eri

(6) be-AOR-Ass3s husband María-GEN 'He is Maria’s husband.'

\section{nanaka-echa-eri jawiri sési ja-rha-X-ti \\ (7) girl-PL-GEN hair well be.there-FT-AOR-Ass3s 'The girls' hair is beautiful.'}

Purepecha is basically a SV and SVO constituent order language, as illustrated by examples (3) and (4). This order is the basic order in the region of Lake Patzcuaro (Capistrán 2002, Chamoreau 2009: 55-8). Other orders indicate specific pragmatic properties. Studies of constituent order in the other regions do not as yet exist. However, Purepecha exhibits some traits of a SOV language: (i) tense, aspect, irrealis and modal markers following the verb; (ii) postpositions; (iii) only suffixes; (iv) only enclitics; (v) case markers; (vi) main verbs preceding inflected auxiliaries; and (vii) variation of the position of head noun in noun phrase that reveals that final head noun precedes non final head noun (compare examples (6) and (7)). SVO and SOV constituent orders were attested in the sixteenth century, and the former has gradually increased since then. The change is 


\section{Purepecha, a Polysynthetic but Predominantly Dependent-Marking Language}

probably due to areal contact. Prior to the Conquest there were speakers of other languages in this territory, mostly Nahuatl (Uto-Aztecan family) and Otomi (Otopamean family), two languages with verb-initial structure. The change probably began under the influence of these languages; (p. 671) Spanish, a SVO language, continued the process, for example by introducing prepositions (Chamoreau 2007).

In Purepecha, the different morphemes that attach to the verb stem are always suffixed. There are two types of stems: a simple stem and a bipartite stem. The stems end in a vowel and generally receive the accent on this vowel, that is, the accent indicates the morphological end of the stem, as illustrated in (8a) and (8b) by a monosyllabic root and in $(8 \mathrm{c})$ by disyllabic roots.
a. $\mathrm{u}$
'do'

(8) b. jwa 'bring'

\section{c. jupa 'wash'}

These simple stems directly accept the inflectional suffixes of third person plural object, tense, aspect, irrealis, and mood, as illustrated in (9) by the verb ewa 'take' to which the third person plural object $-a$, the irrealis $-a$, and the assertive mood for speech act participants (codified as $1 / 2$ ) $-k a$ are suffixed. In (10), the non-finite suffix -ni is directly suffixed to the root kara 'write'.

ewa-a-a-ka

(9) remove-O3PL-IRR-ASS1/2S

'I will remove them.'

$$
\text { mi-ti-xïn-ka=ri }
$$



Example (10) also illustrates the second type, the bipartite stem (DeLancey 1999). These stems are constituted by two bound forms: a root and a suffix. In Purepecha, it is easy to distinguish the verbal root and the derivational element because the latter is not accented and is suffixed to the former. In (10) the root mi- always requires a morpheme before an inflectional suffix. This may be a locative morpheme, as in (11a) and (11b), but it is generally an obligatory suffix whose meaning is not always easy to determinate but may change the meaning of the root, as shown in (11c) and (11d). This is called a formative suffix (Chamoreau 2009: 92-6; Friedrich 1971: 4; Monzón 2004: 53-61). 
(11)

a. mi-tiopen-sup- ' know' (open the forehead / intellectual activity)

b. mi-narhiopen-PRINC- 'recognize' (open the face)

c. mi-ka'close'

\section{d. mi-ta-} 'open'

(p. 672) In Purepecha, the verbal template has a range of potential slots, most of which need not be filled. The template is divided into three main sections; from left to right the order is: stem (slot +1 ); derivational morphemes, more than seventy suffixes (from slot +2 to slot +7 in table 1 ); and flectional morphemes, fifteen suffixes (from slot +8 to slot +12 in Table 32.3). The first section, the stem, has already been introduced: it may be constituted by a simple stem or a bipartite stem. The other two sections have slots that appear in a rigid order, as illustrated in Table 32.1.

\section{Table 32.1 Three main sections of the verbal template}

\begin{tabular}{|c|c|c|c|}
\hline Slots & Types & Categories & Morphemes \\
\hline Root & Stem & root & \\
\hline+1 & & $\begin{array}{l}\text { root }+ \text { formative suffix } \\
\text { bipartite stem }\end{array}$ & \\
\hline+2 & Derivational suffixes & locative & $30 / 50$ suffixes (table 2 ) \\
\hline+3 & & directional & $\begin{array}{l}\text { CENTRIF }-p a \\
\text { CENTRIP }-p u\end{array}$ \\
\hline+4 & & causative & -ra / -ta / -tara \\
\hline+5 & & voice & $\begin{array}{l}\text { REFL - } k u r i \\
\text { REC - } p^{\prime} e r a \\
\text { PASS - } n a \\
\text { ANTIP - } p e \\
\text { APPL3O - } k u \\
\text { APPL1/2O - chi }\end{array}$ \\
\hline
\end{tabular}


Purepecha, a Polysynthetic but Predominantly Dependent-Marking Language

\begin{tabular}{|c|c|c|c|}
\hline+6 & \multirow{7}{*}{ Flexional suffixes } & desiderative & -keka /-ncha \\
\hline+7 & & adverbial & $\begin{array}{l}\text { 'early' -cha } \\
\text { 'quickly' -ma } \\
\text { 'violently' -ntu } \\
\text { 'suddenly' -k'ama } \\
\text { 'iterative' -nt'a }\end{array}$ \\
\hline+8 & & third person plural object & $-a$ \\
\hline+9 & & aspect & $\begin{array}{l}\text { AOR - } x \\
\text { PROG -xa } \\
\text { HAB -xïn } \\
\text { CONT -xam }\end{array}$ \\
\hline+10 & & tense & $\begin{array}{l}\text { PRS unmarked } \\
\text { PAST -p/-an }\end{array}$ \\
\hline+11 & & irrealis & $\begin{array}{l}\text { IRR - } a \\
\text { COND - pirin }\end{array}$ \\
\hline+12 & & $\operatorname{mood}$ & $\begin{array}{l}\text { ASS1/2s }-k a / \text { ASS3S }-t i \\
\text { INT }-k i /-i /-\varnothing \\
\text { SBJV }-k a \\
\text { IMP.SG - }-\varnothing / \text { IMP.PL }-e \\
\text { EXCL }-k^{\prime} a\end{array}$ \\
\hline
\end{tabular}

\section{(p. 673) 32.3 Predominance of Dependent-Marking, Head-Marking and the Possibility of Head Attraction}




\section{Purepecha, a Polysynthetic but Predominantly Dependent-Marking Language}

Purepecha is a predominantly dependent-marking language, as its pronominal markers are enclitics, generally second position enclitics (Section 32.3.1). But in three types of contexts, Purepecha shows features of a head-marking language. In the first type of context, the head-marking characteristic is the consequence of the form of the pronouns: the third person singular is unmarked, and the first person singular may be unmarked. In the second type of context, the third person plural object is a suffix that occurs only in the verb. In the third type of context, the applicative suffix appears exclusively within the verb and encodes a recipient or a possessor (Section 32.3.2). In other contexts, Purepecha shows a head-attraction strategy, as pronominal enclitics have recently begun to appear in a new position, depending on the type of their grammatical host; that is, the enclitics are associated with words that function as the syntactic predicate of the clause (Section 32.3.3). This position makes Purepecha more polysynthetic, as it develops polypersonalism.

\subsubsection{Dependent-marking language}

Subject and object pronouns are expressed by pronominal enclitics. Table 32.2 presents the two paradigms of pronominal enclitics, namely the subject and object enclitics.

This language possesses only enclitics and combines different types-fixed and floating, pronominal and non-pronominal (Chamoreau 2014). Pronominal enclitics are illustrated (p. 674) by example (12) and non-pronominal discourse enclitics by example (13). Both are fixed second-position enclitics. By contrast, adverbial non-pronominal enclitics have a floating position, as in example (14).

Table 32.2 Pronominal enclitics in Purepecha

\begin{tabular}{|c|c|c|}
\hline & Subject & Object \\
\hline 1 & $\varnothing /=n i$ & $=$ reni $(=$ rini $) /=$ ts $^{\prime} \ddot{i n i}{ }^{2}$ \\
\hline 2 & $=r e(=r i)$ & =kini $/$ = kxïni \\
\hline 3 & $\varnothing$ & $\varnothing$ \\
\hline 1PL & $=\operatorname{ch}^{\prime} \mathrm{e}\left(=\mathrm{ch}^{\prime} \mathrm{i}\right) /=\mathrm{kxi}^{1}$ & $=$ ts'ïni \\
\hline $2 \mathrm{PL}$ & $=\mathrm{ts}^{\prime} \ddot{\mathrm{i}}$ & $=\mathrm{kxini}$ \\
\hline 3PL & $=\mathrm{kxi}$ & =kxïni \\
\hline
\end{tabular}


(12)

$\mathrm{ka}=\mathrm{kxï} \quad$ ikya-pa-rini

and=S1PL get.angry-CENTRIF-PTCP.PST.AC

wanto-nts-kwarhe-pa-nt'a-ni

ja-rha-X-p-ka

be.there-FT-AOR-PST-ASS1/2S

'... and, getting angry, we discussed.'

k’orhunta-echa-ni=xï lola-ni ewa-a-a-ka

(13) tamal-PL-OBJ=FOC Lola-OBJ take-O3PL-IRR-ASS1/2S

'They are the tamales that I will bring to Lola.'

(14)

jiniani ire-ka-s-ti, cha-ri $\quad$ tata jingoni=t'u,
there live-FT-AOR-ASs3s s2PL.IND-GEN father COM=too
primu-e-s-ti ima=t'u
cousin-PRED-AOR-ASs3s DEM=too
'He lived up there, with your father too, he is also a cousin.'

It has accented independent pronouns (see the paradigm in Table 32.3). ${ }^{3}$ They are used to introduce or to emphasize a referent, as illustrated in example (15).

(15)

jucha

$$
\text { isï=sï }
$$

mi-ti-s-p-ka

tshirakwa

S1PL.IND

thus $=$ FOC

open-SUP-AOR-PST-ASS1/2S

cold

jimpo

'We thus, knew it for the cold.'

For pronominal enclitics, the second position is their unmarked and more frequent position (see Chamoreau 2014). The pronominal enclitic is used to indicate that the referent (p. 675) functions either as the subject of a clause, as illustrated by $=k s i ̈$ in (16) in an independent clause, or as the object of a clause, as illustrated by =kini in (17) in a dependent clause, whatever the valency of the verb (Chamoreau 2009). In this position, non-pronominal enclitics may be found, as in the case of =taru in (16). One of the functions of a second-position enclitic is to delimit the beginning of a clause, either an independent clause, as in (16), or a dependent clause, as in (17).

Table 32.3 Independent pronouns

Subject

1

ji

\section{Object}

jintini 


\section{Purepecha, a Polysynthetic but Predominantly Dependent-Marking Language}

\begin{tabular}{|c|c|c|c|}
\hline 2 & $t^{\prime} u$ & & t'unkini \\
\hline 1PL & jucha & & juchants'ïni \\
\hline $2 \mathrm{PL}$ & t’ucha / cha & & chankxïni \\
\hline \multicolumn{4}{|c|}{$\begin{array}{lll}\text { no=taru=ksï } & \text { ima-echa-ni } & \text { jatsi-a-s } \\
\text { (16) } \mathrm{NEG}=\text { other }=\mathrm{S} 1 \mathrm{PL} & \text { DEM-PL-OBJ } & \text { have-O3 } \\
\text { 'We no longer had them (papers). } & \end{array}$} \\
\hline \multicolumn{4}{|c|}{$\begin{array}{l}\text { eki=kini juchi } \\
\text { suB=o2sG Poss1sG } \\
\text { on brought you ... }\end{array}$} \\
\hline \multicolumn{4}{|c|}{$\begin{array}{l}\text { Second-position pronominal enclitics have a fixed position within a clause regardless of } \\
\text { the grammatical class of their host. A great variety of hosts is attested; the list below is } \\
\text { organized by frequency of the element that functions as host for second-position enclitics } \\
\text { (see Table } 32.4 \text { ). Adverbs, subordinators, and verbs are the three most frequent } \\
\text { constituents that function as hosts for second-position pronominal enclitics. The high } \\
\text { frequency of the subordinator as host shows that in dependent clauses, pronominal } \\
\text { enclitics almost always attach after this element. At the bottom of the list, postposition } \\
\text { and coordinating conjunctions almost never function as possible hosts. }\end{array}$} \\
\hline \multicolumn{4}{|c|}{$\begin{array}{l}\text { Table } 32.4 \text { Frequency of the constituents in first position to which pronominal enclitics } \\
\text { are attached }\end{array}$} \\
\hline+ frequ & ent & & $\%$ \\
\hline Adverb & & & 19.8 \\
\hline Subordi & Iator & & 17.6 \\
\hline Verb & & & 17.5 \\
\hline Deictic r & narker & & 10.8 \\
\hline Demons & rative pronoun & & 9.8 \\
\hline Indepen & lent pronoun & & 8.1 \\
\hline
\end{tabular}




\section{Purepecha, a Polysynthetic but Predominantly Dependent-Marking Language}

Interrogative pronoun

Negation

Noun, noun phrase

Postposition

Coordinating conjunction
5.6

\section{- frequent}

(p. 676) Different enclitic strings, also known as clitic clusters, are possible in Purepecha.

- two non-pronominal enclitics, as in (18)

- one non-pronominal and one pronominal enclitic, as in (16)

- two non-pronominal enclitics and one pronominal enclitic, as in (19).

\section{sani k'e-ni ka, no=teru=chk'a \\ (18) little grow-NF and $\mathrm{NEG}=$ other=certainly gain-INTS-NF 'He grows a little, and this is not sufficient.'

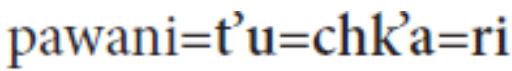 \\ (19) tomorrow $=$ too $=$ certainly $=\mathrm{S} 2 \mathrm{SG}$ 'Also tomorrow, you will go.' \\ ni-a-ka \\ go-IRR-ASS1/2S}

Enclitic strings have a strict internal order: the non-pronominal enclitic precedes the pronominal enclitic as illustrated in (19). However, two non-pronominal fixed enclitics, the focus $=s i ̈$ and the evidential $=n a$, generally appear at the end of the string (except with first person singular that appears after the focus =xi). In the sixteenth century, the order was the reverse, that is, =pronominal =non-pronominal. Today, the fixed position shows some signs of weakening. Non-pronominal enclitics keep their position, while pronominal enclitics exhibit variation, tending to move to the right position in the clause, and may encliticize to the predicate itself (see Section 32.3.3).

\subsubsection{Contexts of head-marking characteristics}

Third person singular is always unmarked regardless of the mood, in assertive mood, as illustrated in (20), in interrogative mood, as shown in (21), and in subjunctive mood, as illustrated in (22). In (20c), (21c), and (22c), the absence of pronominal marker is understood as the third person singular. 


$\begin{array}{ll}\text { a. kara-s-ka / kara-sïn-ka=ni } & \begin{array}{l}\text { 'I wrote' } \\ \text { b. kara-s-ka=ri }\end{array} \\ \text { (20) } \begin{array}{l}\text { c. kara-s-ti } \\ \text { d. kara-s-ka=ksï }\end{array} & \text { 'He wrote' } \\ \text { e. kara-s-ka=ts'ï } & \text { 'We wrote' } \\ \text { f. kara-s-ti=ksï } & \text { 'You (pl.) wrote' } \\ \text { a. kara-s-ki=ni } & \text { 'They wrote' } \\ \text { b. kara-s-ki=ri } & \text { 'Have I written?' } \\ \text { c. kara-s-ki } & \text { 'Have you (sg.) written?' } \\ \text { d. kara-s-ki=ksï } & \text { 'Has he written?' } \\ \text { e. kara-s-ki=ts'ï } & \text { 'Have we written?' } \\ \text { f. kara-s-ki=ksï } & \text { 'Have you (pl.) written?' }\end{array}$

(p. 677)

a. eka=ni kara-ø-ka

b. eka=ri kara-ø-ka

(22)

c. eka kara-ø-ka

d. eka=ksï kara-ø-ka

e. eka=ts'ï kara-ø-ka

f. eka=ksï kara-ø-ka 'when I wrote'

'when you (sg.) wrote'

'when he wrote'

'when we wrote'

'when you (pl.) wrote'

'when they wrote'

As illustrated in (20), the assertive mood is -ka for speech act participants, as in (20a, b, $\mathrm{d}, \mathrm{e})$, and -ti for third persons, as in (20c, f). Interestingly, in this mood two of the persons -the first person singular and the third person singular-may have a zero marker when they function as the subject: the third person singular is always unmarked whereas the first person singular has two possibilities. For the first person there is no difference in the use of the covert marker or the overt $=n i$. In the sixteenth century the use of the unmarked form was the most frequent (Chamoreau 2014). There are two ways of identifying the referent in assertive clauses: The absence of the enclitic is always interpreted as first person singular with $-k a$, as in (20a); by contrast, in the case of other persons the enclitic or independent pronoun is used, as in (20b), (20d), and (20e). With a mood other than the assertive, for the interrogative or subjunctive, which have the same morpheme for all the persons, the enclitic (or the independent pronoun) is introduced, as in (21a) and (22a).

The consequence is that Purepecha shows head marking or polypersonalism with third person in all moods and with first person in the assertive mood. The other context in which Purepecha displays head-marking behavior is with the third person plural object 


\section{Purepecha, a Polysynthetic but Predominantly Dependent-Marking Language}

suffix. This is the unique suffix for pronominal encoding that occurs exclusively in the verb. The suffix - $a$ occurs only for third person plural when it functions as the object of the clause, as illustrated in (23).

\section{che-ra-a-xïn-ti \\ (23) be_afraid-CAUS-O3PL-HAB-ASS3S 'He scares them.'}

The presence of $-a$ is not obligatory when the object is the third person plural. The presence or absence of the object suffix depends on the way the referent of the noun is conceived. When the noun refers to various entities that can be individuated, the suffix is used as in (24a), but when the same entities are understood as unindividuated, the suffix does not appear, as illustrated in (24b) (Chamoreau 2009: 84-91). In the context of body parts or objects that always function in pairs (eyes, ears, legs, arms, etc.), the noun generally is not marked by the -echa marker but the suffix - $a$ is attached to the verb, as in (25). This suffix is not a marker of agreement of a noun in the plural, in the sense that its presence is not obligatory.

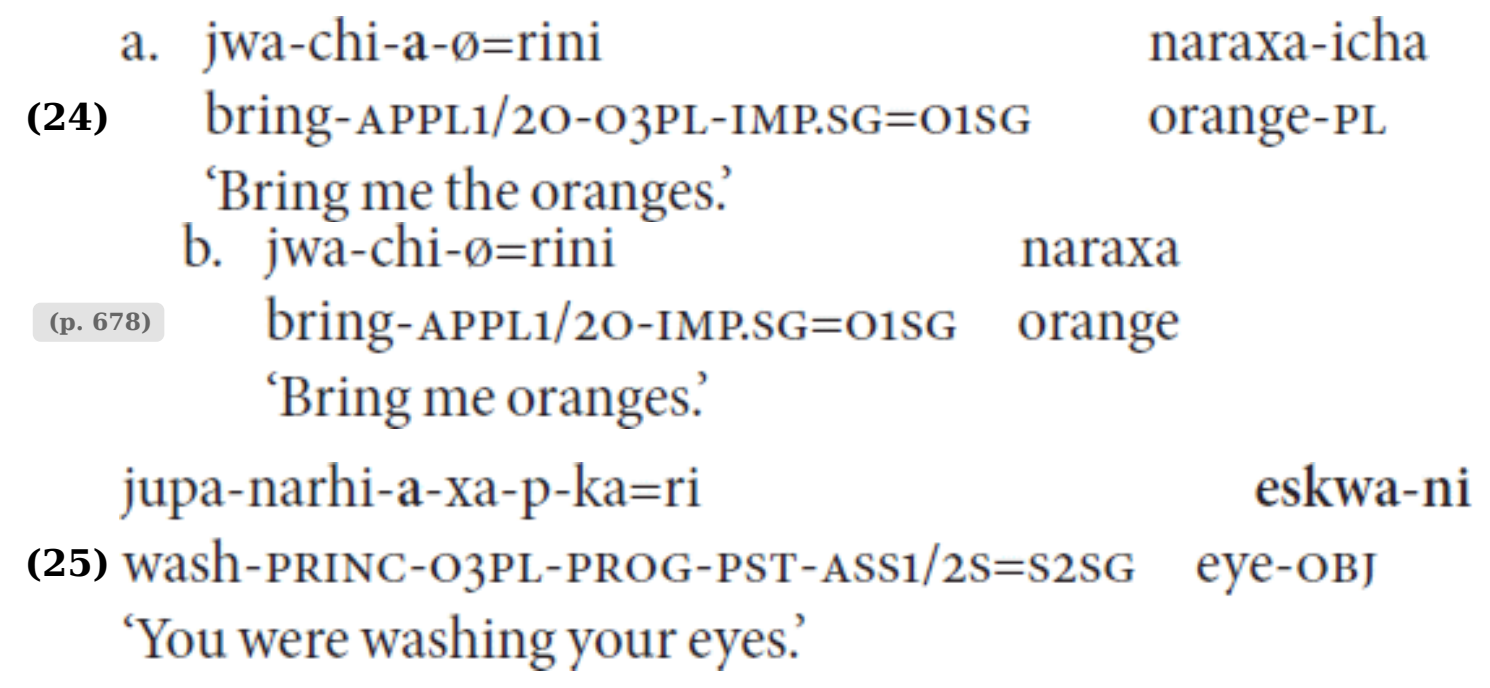

In Purepecha, there are two suffixes for applicative voice: -chi for speech act participants $(1 / 2)$ and $-k u$ for the other participants. The use of applicative voice allows the introduction of the recipient or the beneficiary as illustrated in (26a). In (26b), two interpretations are possible: the applicative suffix introduces the beneficiary or the possessor of the entity expressed as second argument wichu-ni (external possession). 
a. anchi-kurhi-chi-xïn-ti=rini

work-FT- APPL1/2O-HAB-ASS3S=O1SG

'He works for me'.

(26)

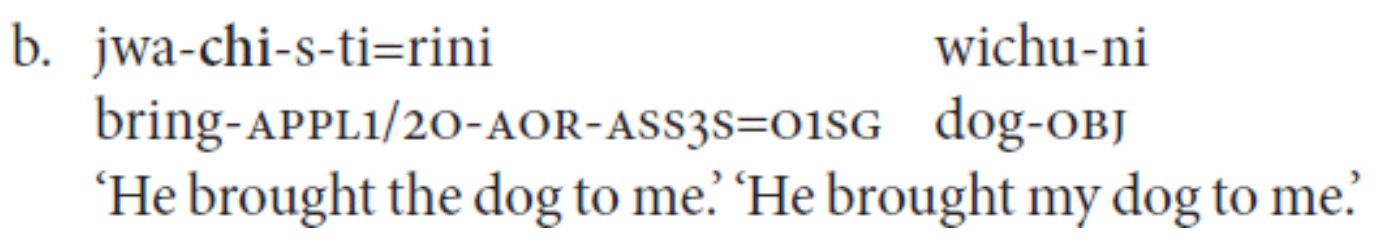

To sum up: Purepecha is a predominantly dependent-marking language, as the arguments are coded as second-position enclitics (see Section 32.3.1). But it shows head marking or polypersonalism with the unmarked third person singular form and the first person singular form in the assertive mood. This head-marking characteristic is also attested with third person plural object suffix codified within the verb and when a suffix of applicative voice is attested.

\subsubsection{Head attraction}

In Purepecha, pronominal enclitics have recently begun to appear in a new position, after the syntactic predicate of the clause, frequently a verb. For methodological reasons, I treat predicate enclitics as different from verbs in first position that are hosts for secondposition pronominal enclitics. In Table 32.4, verbs are one of the three most frequent constituents that function as the host of second-position pronominal enclitics. This is not a surprise in the case of verbs, as it is a well-known feature cross-linguistically (Givón 2011a: 182; Heine and Song 2011). But it is new in Purepecha: in the sixteenth century, verbs were generally not positioned at the beginning of a clause (Chamoreau 2014). The high frequency of verbs as hosts of second-position enclitics is significant in a narrative with chain-medial clauses, which contain non-finite clauses with referential continuity; these chain-medial clauses are only constituted by predicates that express a succession of events or indicate overlapping events, as illustrated by example (27) (see Section 32.5 and Chamoreau 2016). The verb (p.679) occurs more frequently in first position, and becomes a "frequent candidate to host second-position clitics" (Givón 2011: 190). In this context, generally only the pronominal enclitic that functions as subject is expressed. 




b. tsipi-pa-nt'a-ni=kxï,

(27)

$$
\begin{aligned}
& \text { be.happy-CENTRIF-IT-NF=S3PL } \\
& \text { they were happy, }
\end{aligned}
$$

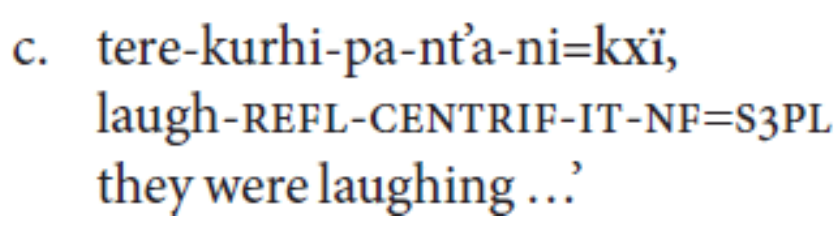

In the new strategy, enclitics are attached to the end of the predicate after the aspect, tense, and irrealis mood markers. This is also a fixed position, but what has changed is that predicates need not appear in the first position of the clause, but can appear in any position. This movement to the right, from second-position enclitic to predicate enclitic, occurs only with pronominal enclitics. The host is chosen for its syntactic and pragmatic properties, and is frequently the predicate itself, as illustrated by example (28), or in a few cases the last element before the predicate, when it is an adverb or a negation, as in (29).

(28)

$\begin{array}{lll}\text { ka yontki anapu ire-kwari-p-ti=ksï } & \text { Chao } \\ \text { and before origin reside-REF-AOR.PST-ASs3S=S3PL } & \text { Chao } \\ \text { 'and since before they lived in Chao.' } & \end{array}$

(29)
xani
arhi-a-xïn-ka=ni
éxki
no=kxï
much say-S3PL-HAB-ASS1/2S=S1SG
COMP NEG $=$ S3PL
itsu-ta-ø-ka
'I always ask them not to smoke.'

Five new morphosyntactic possibilities for the new strategy have been identified. Going from the most frequent strategy to the least frequent, these are:

1. After the predicate: this is more frequent for the subject, as in (28), than for the object, as in (30).

2. Pronominal agreement: independent pronoun and enclitic after the predicate, as in (31).

3. Repetition of the enclitic that functions as the subject (in the same clause): as the second-position enclitic and after the predicate (32). For the object, this strategy has not been found to occur. 


\section{Purepecha, a Polysynthetic but Predominantly Dependent-Marking}

\section{Language}

4. Pronominal agreement: independent pronoun, second-position enclitic, and enclitic after the predicate, as in (33). This strategy has been found for the subject, never for the object.

5. After an element that occurs before the predicate: generally negation (29), but there are two examples with an adverb (34). This strategy has been found for the subject, never for the object.

\section{(p. 680) 32.3.3.1 Examples of the new morphosyntactic possibilities}

1. After the predicate:

(30)

\begin{tabular}{|c|c|c|}
\hline jima pia-chi-a-ti=kini, & eki=rini & ixe-ø-ka \\
\hline buy-APPL1/2O-IRR-ASS3S=O2SG & $\mathrm{SUB}=\mathrm{O} 1 \mathrm{SG}$ & see-AOR-SBJV \\
\hline
\end{tabular}

2. Pronominal agreement: independent pronoun and enclitic after predicate:

(31)

$\begin{array}{lllll}\mathrm{ka} \text { t'u } & \text { tata } & \text { generali-i-X-ki=ri } & \text { a } & \text { no } \\ \text { and s2sG.IND } & \text { sir } & \text { general-PRED-AOR-INT=S2SG } & \text { ah } & \text { NEG } \\ \text { 'and, you are the general, aren't you?' } & & \end{array}$

3. Repetition of the enclitic:

(32)

$\begin{array}{lll}\text { jimpoki=ni } \quad \begin{array}{l}\text { yontki=t'u } \quad \text { unta- } \emptyset-\mathrm{ka}=\mathrm{ni} \\ \text { suB=S1SG } \quad \text { before=too begin-AOR-SBJV=S1SG }\end{array} & \begin{array}{l}\text { a-rha-ni } \\ \text { divide-FT-NF }\end{array} \\ \text { 'because before I also began to drink.' } & \end{array}$

4. Pronominal agreement: independent pronoun, second-position enclitic, and enclitic after predicate:
eki=ni
ji
ni-nt'a-p-ka=ni
(33) $\mathrm{SUB}=\mathrm{S} 1 \mathrm{SG}$
S1SG.IND
gO-IT-AOR.PST - SBJV $=$ S1SG
'When I came back ...'

5. After an element that occurs before the predicate:

(34)
tepekwa-icha
nanaka-icha-iri
sési=kxï
ja-rha-x-ti
braid-PL
girl-PL-GEN
well $=\mathrm{S} 3 \mathrm{PL}$
be.there-FT-AOR-Ass 3 S
'The girls' braids are beautiful.'

Quantitative data are highly relevant to proving that the predicate enclitic ought to be viewed as a new strategy that is marked and infrequent. I have gathered a corpus of 123 texts (narrative and conversation) in which I count 4,182 pronominal enclitics: 3,710 


\section{Purepecha, a Polysynthetic but Predominantly Dependent-Marking Language}

function as the subject and 472 as the object. This result shows that the majority of the clauses are intransitive or transitive with a third person object. In this corpus, only 228 pronominal enclitics, or 5.5 percent, were not found in the second position. The predicate enclitic is very infrequent: 209 of these enclitics function as the subject and 19 as the object. Another finding is that 216 enclitics occur in main clauses, 12 in dependent clauses. In dependent clauses, the referent frequently attaches after the subordinator. Table 32.5 displays the different strategies for codifying referents (outside the nominal codification). These are generally expressed by (p.681) a pronominal enclitic, and only very infrequently by an independent pronoun (line g). The non-predicate enclitic position accounts for 94.5 percent of the occurrences in only three types of position, namely (a), (e), and (g). Conversely, the predicate enclitic only accounts for 5.5 percent, and in five types of position, (b), (c), (d), (f), and (h). Table 32.5 also shows the current variation in the codification of referents in particular as enclitics. The development of the predicate enclitic explains this variation. Another consequence is an increase in the contexts in which independent pronouns are used. In the sixteenth century, independent pronouns were infrequent (Chamoreau 2014).

\begin{tabular}{|l|c|}
\hline Table 32.5 Frequency of ways to codify grammatical participants & \% \\
\hline + frequent & 93.8 \\
\hline \begin{tabular}{l} 
a. Second position \\
\hline b. After the predicate (not in second position)
\end{tabular} & 2.9 \\
\hline c. Independent pronoun + after the predicate & 1.6 \\
\hline d. Second position + after the predicate & 0.5 \\
\hline e. Independent pronoun + second position & 0.5 \\
\hline f. Independent pronoun + second position + after the predicate & 0.3 \\
\hline g. Independent pronoun & 0.2 \\
\hline h. After an element that occurs before the predicate & 0.2 \\
\hline - frequent & \\
\hline
\end{tabular}

The analysis of the corpus identifies some specific texts in which the use of predicate enclitics (not in second position) is more frequent. These texts display two types of pragmatic and sociolinguistic characteristics. On the one hand, there are autobiographical stories or narratives with only one or two referents, that is, narratives in which the main referent has a very prominent role and exhibits high continuity. On the 


\section{Purepecha, a Polysynthetic but Predominantly Dependent-Marking Language}

other hand, texts with a frequent use of predicate enclitics are narrated by bilingual speakers who have had at least an intermediate-level school education or who use Spanish more than Purepecha in everyday communication. There are three representative texts. The first text is an autobiographical story told by a Purepecha speaker who uses Purepecha in everyday communication (see Chamoreau 2012 for more details). Predicate enclitics represent 18 percent of total enclitic occurrences. The second story is told by a man from Arantepacua who has studied in Morelia and has responsibilities in his village; he uses Spanish more than Purepecha. In his account of a traditional legend, 14 percent of the occurrences are predicate enclitics. The third example is an autobiographical story by a woman who lives in Mexico City (story cited by Capistrán 2004). In this text, 36 percent of the occurrences are predicate enclitics.

How has this variation in pronominal enclitics become possible? Two related hypotheses may be advanced to answer this question. The first hypothesis for explaining change in predicate position and its restriction to pronominal enclitics is that pronominal enclitics choose their hosts because of their syntactic and discourse properties, exhibiting head attraction (see Haig 2008 for Western Iranian languages). Syntactic predicates generally express the main information. Cases of head attraction for pronominal enclitics are described in the (p. 682) literature for Iranian languages (Haig 2008) and Romance languages (Vincent 2001). In earlier stages, ancient Iranian and Latin possessed pronominal second-position clitics. Today, Persian and Romance languages have pronominal markers placed close to the verb, usually within the verb phrase. This shift was analyzed by Haig (2008) as a case of attraction to the verb, that is, to the head that governs pronominal markers. In Purepecha, the process began centuries ago when the pronominal enclitics moved to the end of the second-position enclitic string (see Section 32.3.1 and Chamoreau 2014). This process allowed the pronominal enclitics to move to the last position and to gain more freedom to move. The second hypothesis is based on analysis of characteristics of the speakers who narrated the texts with more frequent predicate positions: Spanish grammatical constructions may influence the change of position of pronominal enclitics in Purepecha (Chamoreau 2007, 2012). Spanish expresses the referents close to the verb as clitics or in the flexion associated with tense and mood (Vincent 2001). Almost all Purepecha speakers are bilingual, speaking at least Purepecha and Spanish. Spanish is the language of prestige, linked to education, a better standard of living, oral and written media, religion, administration, commerce, and work. The speakers who narrated these texts use Spanish more frequently in everyday conversation.

In short, Purepecha exhibits variations in position, distribution (predicate), frequency (increase in pronominal enclitics attached to the verb), and grammatical function (from clause delimitation to marking the predicate in whatever position). These variations are the consequences of new tendencies that give more relevance to predicates, showing head attraction and making Purepecha more polysynthetic as it displays polypersonalism in these contexts, as illustrated in Sections 32.3.2 for head marking and 32.3.3 for head attraction. 


\subsection{Verbal Morphology}

One of the most frequently described characteristics of polysynthetic languages is the combining of bound morphemes with the verb (Evans and Sasse 2002, Drossard 2002, Fortescue 1994, Mithun 2009). In Purepecha, locative suffixes are particularly numerous; this is the wider class of derivational suffixes. Other types of derivational suffixes are less developed: there are two directional suffixes, two desiderative suffixes, five adverbial suffixes, three causative suffixes and five suffixes for voice change (as illustrated in Table 32.1).

\subsubsection{Locative suffixes}

Between thirty and fifty morphemes belong to the class of locative suffixes. Friedrich lists thirty-two (1971: 15-16), and Monzón has studied forty-six (2004: 67). This variation may be due to dialectal differences. In Table 32.6, I present the thirty suffixes attested in Jaracuaro.

In Purepecha, these locative suffixes are lexical suffixes that exhibit characteristics similar to those described by Mithun $(1997,2009)$ for the lexical affixes of the Salishan languages. The locative suffixes constitute a closed paradigm of exclusively dependent morphemes that may suffix to the verbal stem (see Table 32.6). They have a lexical meaning basically related to spatial concepts, which include parts used for the body, for the majority of the suffixes.

(p. 683) The class of locative suffixes breaks down into two semantic subclasses. The first consists of morphemes that indicate a specific physical area (outside the body), for example in (35a) -nu 'patio', in (35b) -ru 'street', and in (35c) -k'ara 'inside the house'.

\section{a. waxa-nu-x-ti 'He sat on the patio.' \\ (35) b. waxa-ru-x-ti 'He sat in the street.' c. waxa-k'ara-x-ti 'He sat inside the house.'}

The elements of this first subclass are not numerous; the majority of the locative suffixes belong to a second subclass that refers to a part of a larger entity. Example (36) illustrates a suffix of this subclass: the suffix -narhi refers to the principal part of a larger area. In the situation in (36), the part is obligatorily interpreted as a body part and the possessor of the face is the referent of the entity that functions as subject. There is no ambiguity; no independent locative noun is required to specify the body part. When -narhi refers to a subpart of the face of the referent of the subject, the eye for example, an independent spatial noun is obligatory. This noun may be marked by the objective case or by the locative case, as illustrated in (37). When -narhi refers to the face or a subpart of 


\section{Purepecha, a Polysynthetic but Predominantly Dependent-Marking Language}

the face of another participant, a non-coreferential subject suffix is required, for example $-k u$, as illustrated in (38).

$$
\begin{aligned}
& \text { jupa-narhi-Xa-p-ka=ri } \\
& \text { (36) wash-PRINC-PROG-PST-ASS1/2S=S2SG } \\
& \text { 'You were washing your face.' }
\end{aligned}
$$

(37)

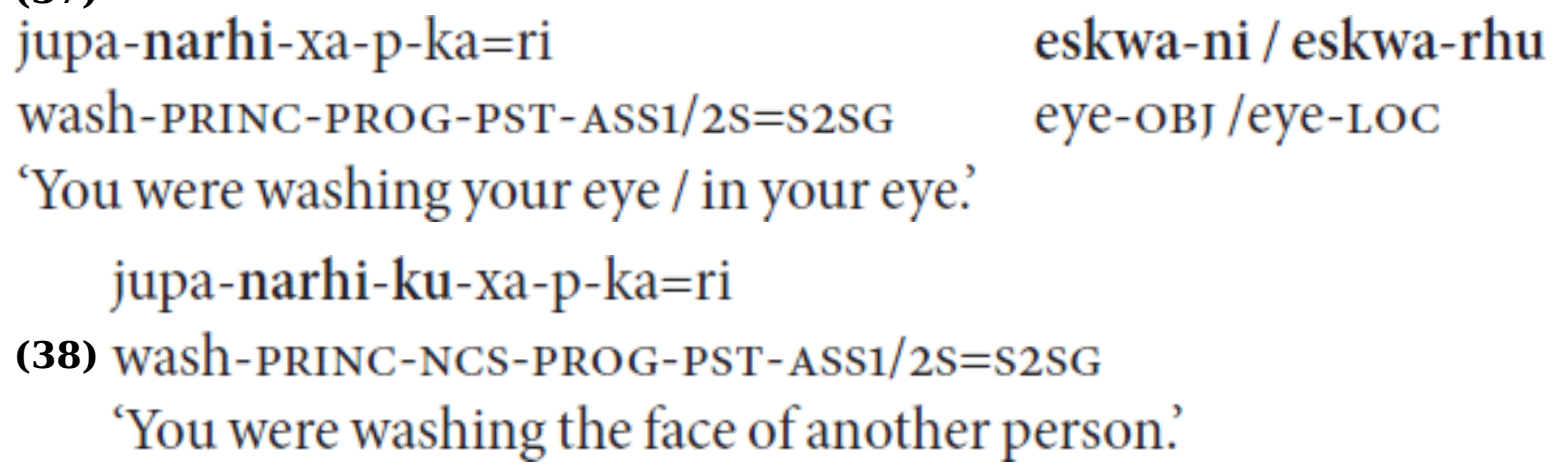

These suffixes are considered abstract because they may be used for areas outside the body. The suffix -narhi may refer to the sun, as in (39), to an emotion of fright, as in (40), to the center of a dish, as in (41), or to a wall, as in (42) (for more details, see Chamoreau 2009: 224-6, Friedrich 1971: 43-7, Monzón 2004: 128-33). In examples (40) and (41), a non-coreferential subject suffix is used:- $k u$, as in (41), and -ta, as in (42). The distribution of these suffixes depends on dialectal variation and on the conception of the referent as animate or inanimate (for more details, see Friedrich 1971: 55-67, Monzón 2004: 25279). The meanings of these suffixes are abstract and refer to geometrical features, even though the most frequent use is for a body part (Friedrich 1971, Monzón 2004). Their meanings are wider or more general than the noun that might seem to have a similar meaning: for example, the suffix -narhi refers to a principal flat area and may be used for face, hair, eye, sun, light, wall, texture, and leaf, but also for emotional states such as fear and dream. A single noun cannot subsume all (p.684) these contexts of use. Relations between suffixes and nouns are not straightforward even if the body part meaning seems to be the reference from which metaphoric and abstract extensions are made (Mithun 1997: 359). Moreover, there are no formal similarities between the suffixes and the noun that has related meaning. For example, the suffix that refers to the hair is $-t s i ̈$, whereas the noun for the hair is jawiri. This is the reason why they do not correspond to a path of development from noun incorporation.

\section{jurhiata mere-mere-narhi-xïn-ti \\ (39) sun shine-shine-PRINC-HAB-ASs3s \\ 'The sun shines a lot.'}




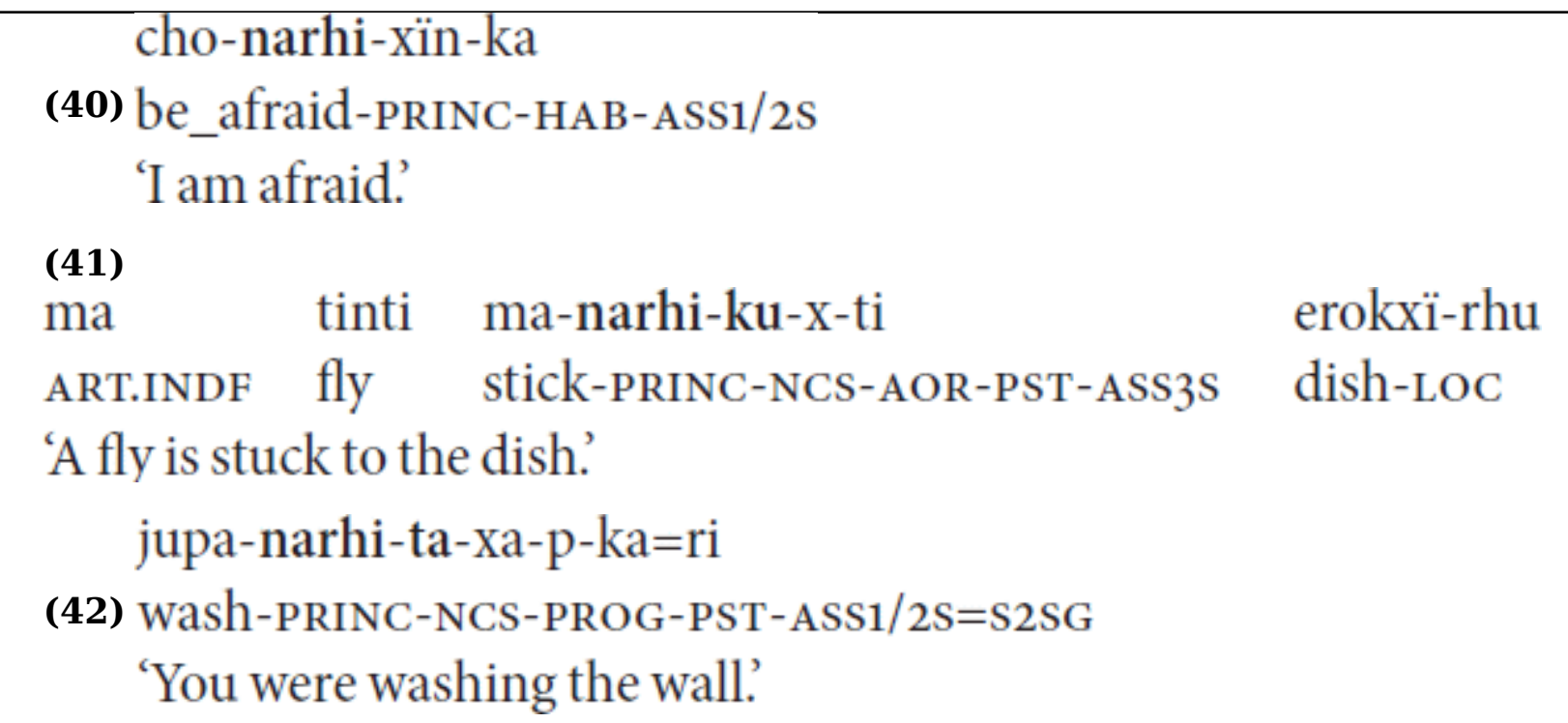

A relevant syntactic feature of this type of suffix is a co-referential relation with an argument of the verb. These suffixes generally refer to a part belonging to the referent of the entity that functions as the subject, as illustrated in (36), (37), and (38). But a small number of morphemes are directly co-referential with a part that belongs to the participant codified as the object, as illustrated in (43), and the reflexive morpheme -kuri is required when this body part belongs to the participant codified as the subject, as in (44) (Monzón 2004: 221-4, 235-42).

\section{era-ti-s-ti \\ (43) look-suP-AOR-Ass3s \\ 'He looked at somebody'. \\ era-ti-kuri-s-ti \\ (44) look-SUP-REFL-AOR-ASs3s \\ 'He looked at himself.'}

They may co-occur with an independent noun phrase that has the same meaning as the suffix or that specifies a subpart included in a larger part denoted by the suffix. This phrase may function as subject, as in (39), object or locative noun phrase as in (37). They may be (p.685) (p.686) co-referential with an argument or a noun that functions as subject, object, or locative noun phrase.

Table 32.6 Locative suffixes found in Jaracuaro (Chamoreau 2009: 221-30)

\begin{tabular}{l|l|l|} 
Suffix & Meaning & Context of use \\
\hline a & central area & stomach, uterus, intestines, field \\
\hline
\end{tabular}




\begin{tabular}{|c|c|c|}
\hline cha & large and narrow area & $\begin{array}{l}\text { neck, throat, larynx, penis, grain, oral function } \\
\text { (criticize) }\end{array}$ \\
\hline ch'u & $\begin{array}{l}\text { lower and bottom } \\
\text { area }\end{array}$ & buttocks, bottom, background \\
\hline kurhi & crossing area & waist, crossing area, malformation \\
\hline k'arha & $\begin{array}{l}\text { interior of a house } \\
\text { area }\end{array}$ & \\
\hline $\mathbf{k}^{\prime} \mathbf{u}$ & $\begin{array}{l}\text { extremity and upper } \\
\text { area }\end{array}$ & arm, hand, leaf, tissue \\
\hline $\begin{array}{l}\text { ma } / \\
\text { mi }\end{array}$ & open area with liquid & $\begin{array}{l}\text { mouth, lips, teeth, shin, liquid, oral function } \\
\text { (miaow) }\end{array}$ \\
\hline marhi & orifice-edge area & $\begin{array}{l}\text { out of the mouth, out of place, oral function } \\
\text { (yawn) }\end{array}$ \\
\hline marhu & crotch & \\
\hline mu & $\begin{array}{l}\text { orifice and orifice- } \\
\text { edge area }\end{array}$ & $\begin{array}{l}\text { mouth, chin, lips, open area, oral function (order, } \\
\text { blow) }\end{array}$ \\
\hline na / ni & interior area & chest, breast, interior, shirt \\
\hline narhi & $\begin{array}{l}\text { principal and flattish } \\
\text { area }\end{array}$ & $\begin{array}{l}\text { face, hair, eye, sun, light, wall, food, leaf, be } \\
\text { afraid, dream }\end{array}$ \\
\hline nti & $\begin{array}{l}\text { external and } \\
\text { peripheral area }\end{array}$ & $\begin{array}{l}\text { ear, branch soil, auditory function, atmospheric } \\
\text { phenomena, quiet }\end{array}$ \\
\hline ntira & $\begin{array}{l}\text { external area of an } \\
\text { edge }\end{array}$ & $\begin{array}{l}\text { mouth, cheek, chin, teeth, feminine sex, oral } \\
\text { function (lie) }\end{array}$ \\
\hline ntu & lower outer area & foot, base of a tree or plant, field \\
\hline nu & basic and central area & patio \\
\hline $\begin{array}{l}\text { p'a } / \\
\mathbf{p}^{\prime} \mathbf{i}\end{array}$ & front area & fire, front \\
\hline
\end{tabular}




\begin{tabular}{|c|c|c|}
\hline parha & long exterior area & $\begin{array}{l}\text { back, shoulder, outer part of the wall, load, cost, } \\
\text { dress }\end{array}$ \\
\hline $\mathbf{p}^{\prime} \mathbf{i}$ & body & \\
\hline ru & road, street & \\
\hline rhi & external body area & body, trunk \\
\hline rhu & $\begin{array}{l}\text { projection of } \\
\text { something longish }\end{array}$ & $\begin{array}{l}\text { nose, forehead, tip, hanging fruit, olfactory } \\
\text { function }\end{array}$ \\
\hline $\begin{array}{l}\text { ta } / \\
\text { nta }\end{array}$ & $\begin{array}{l}\text { around the side of } \\
\text { something }\end{array}$ & \\
\hline ti & top, upper area & $\begin{array}{l}\text { top of the face, eyes, intellectual activity } \\
\text { (knowing) }\end{array}$ \\
\hline t'a & flat and vertical area & leg, side \\
\hline tsi & lower area & $\begin{array}{l}\text { lower surface, lower ground, states perceived as } \\
\text { negative (thin, shame) or carried out in secret }\end{array}$ \\
\hline tsï & top area & $\begin{array}{l}\text { hair, skull, head, hat, top surface, spiritual } \\
\text { activity }\end{array}$ \\
\hline xa & flat area & knee, braid \\
\hline xu & arm & \\
\hline rh & knee articulation & \\
\hline
\end{tabular}

In Purepecha the majority of the nouns are built from verbal stems with the addition of a nominalizer suffix. As a result, the lexical suffixes may also appear in deverbal nouns (Friedrich 1971, 1984; Monzón 2004). For example, the verb era-ti-kuri 'look at superior area oneself', as illustrated in (44) forms the noun eratikurita 'mirror' with the nominalizer - $t a$. These suffixes also serve as devices for creating neologisms, for example era-nari- 'look at principal area' forms a noun with the nominalizer -kwa. This noun eranarikwa was created for 'photography'. The suffixes make the meaning of the verb to which they bind more specific by indicating the participation of certain locative parts in the event. 


\section{Purepecha, a Polysynthetic but Predominantly Dependent-Marking Language}

\subsubsection{Other derivational suffixes}

Other types of derivational suffixes are less developed in Purepecha: there are two directional suffixes, two desiderative suffixes, and five adverbial suffixes. Purepecha has three causatives (with three allomorphic suffixes) and five suffixes for voice change.

There are two directional suffixes, one for centrifugal direction, as illustrated in (45), and one for centripetal direction, as illustrated in (46). The directional suffixes encode the information in a more synthetic way and avoid the use of the two verbs that mean 'go' and 'come'. As in the case of locative suffixes, there are no formal similarities between the suffixes and the verb which has the same meaning: the suffix that refers to centrifugal direction is - $p a$, and the verb 'go' is ni; the suffix - $p u$ means 'come' and the verb 'come' is $j u$. There is no evidence of a nominal or verbal source for the affixes.

$$
\text { kwi-para-pa-a-ka=kini }
$$

(45) carry-LONG.EXT-CENTRIF-IRR-ASS1/2S= O2SG

'I will go carrying you on my back.'

chkari-ni kachu-ku-pu-xa-ti

(46) wood-OBJ cut-FT-CENTRIP-PROG-ASS3S 'He comes cutting the wood.'

Desiderative and adverbial suffixes appear in the last slots of the derivational suffix complex. The use of desiderative suffixes is common, whereas the use of adverbial suffixes is unusual. The two desiderative suffixes are -keka 'desire' and -ncha 'have a fancy for, want' as in (47). The verbs that mean 'desire, have a fancy for, want' are tsitsi and wé. As seen with locative and directional suffixes, there is no similarity between the form of the suffixes and the verbs that have a similar meaning.

u-ncha-a-s-ka=ri

(47) do-DES-O3PL-AOR-ASS1/2S=S2SG

'You desired to make them (tamales, in this situation).'

(p. 687) Five adverbial suffixes have been found: -cha 'early', -ma 'quickly', -ntu 'violently', - $n t^{\prime} a$ 'iterative', and -k'ama 'suddenly' (Monzón 2004: 65-7). The suffixes - $k$ 'ama, as in (48a), and $-n t^{\prime} a$, as in (48b) are the most frequent. 
a. incha-k'ama-x-ti=kxï

enter-suddenly-AOR-Ass3s $=$ S3PL 'They enter suddenly'

b. janó-nkwa-nt'a-s-ti

ireta-rhu

arrive-CENTRIP-IT-AOR-Ass3s village-LOC 'He returned to the village.'

Purepecha has three suffixes for the causative: $-r a$, -ta, and the combination of both, -tara. These three morphemes have a distribution depending on the type of stem (Capistrán 2010; Maldonado and Nava 2002). The causative -ra appears after simple stems, that is, roots that directly accept the inflected suffixes of third person plural object, tense, aspect, irrealis, and mood (see Section 32.2), as illustrated in (49), and verbs that denote properties, as illustrated in (50).

thiri-ra-a-x-ka

(49) eat-CAUS-O3PL-AOR-ASS $1 / 2 \mathrm{~S}$

'I gave to eat to them.'

te-ra-X-ti itsï-ni

(50) become_sweet-CAUS-AOR-Ass 3 s water-oBJ

'He sweetened the water.' ('He made sweet the water.')

The suffix -ta generally occurs after a locative suffix, as in (51):
ana-t'a-ta-s-ti
tsintsikata-rhu
(51) be_vertical-VERT-CAUS-AOR-ASs 3 S wall-LOC 'He stood him up near the wall.'

The suffix -tara is attached to bipartite stems that have another suffix after the root (except locative suffixes), for example formative suffixes, as illustrated in (52):

(52)
jaka-k’u-tara-xa-ti=rini
ixka
tumpi-i-ø-ka
believe-FT-CAUS-PROG-ASs3S=O1SG
COMP
young-PRED-AOR-SBJV
'He makes me believe that he is young.'

These suffixes generally indicate direct causation. In Purepecha, double causation is possible. In this context, the causative morpheme slot is filled by two morphemes. In (53a), the verb te- is intransitive. In (53b), with one causative morpheme - $r a$, the verb teis (p. 688) transitive and takes two arguments; by contrast, in (53c) we can recognize a 
double causation, using two causative morphemes -ra and -tara. The result is a ditransitive verb. The causer is the subject of the clause and the causee is encoded as a syntactic object in the clause, Celia-ni.

\title{
(53)
}
a. itsï te-X-ti
water become_sweet-AOR-Ass3s
'The water became sweet.'

b. te-ra-x-ti

itsï-ni

become_sweet-CAUS-AOR-Ass3s water-oBJ

'He sweetened the water.' ('He made sweet the water.')
c. te-ra-tara-x-ti
become_sweet-CAUS-CAUS-AOR-ASs3s
itsï-ni
celia-ni
'He made Celia sweeten the water.'

Purepecha distinguishes five suffixes for voices: the reflexive voice is marked by the suffix -kuri, in (54), -kuri is also used for the middle voice, as illustrated in (55) (other suffixes exist for marking the middle voice, see Nava 2004); the reciprocal voice is marked by the suffix -pera in (56); the passive voice is codified by the suffix -na, in (57), -na is also used for the impersonal voice as in (58); the antipassive voice is marked by the suffix -pe, in (59); and the applicative voice is codified by two suffixes (see Section 32.3.2), one for speech act participants (1/2), the suffix -chi, in (60), and the other for third persons, the suffix $-k u$, as illustrated in (61).

REFLEXIVE
pa-kuri-s-ti
thirikwa
(54) take-REFL-AOR-Ass 3 s food
'She took the food for her/ She took her food.'

MIDDLE

\author{
mikwa mi-kuri-x-ti \\ (55) door \\ open-REFL-AOR-ASS3S \\ 'The door closed up.'
}

RECIPROCAL 
jura-p’era-xïn-ti=kxï

(56) separate-RECP-HAB-ASS $3 \mathrm{~S}=\mathrm{S} 3 \mathrm{PL}$

'They cut among themselves.'

PASSIVE

misitu ata-na-na-x-ti

(57) misitu beat-INTR-PASS-AOR-ASS3S

'The cat was beaten on the chest.'

(p. 689) IMPERSONAL

warha-na-xa-ti

(58) dance-PASS-PROG-ASS3S

'They are dancing.' 'One is dancing.'

ANTIPASSIVE

$$
\begin{aligned}
& \text { meya-pe-xïn-ka k'urunta } \\
& \text { (59) trade-ANTIP-HAB-Ass1/2s tamale } \\
& \text { 'I sell tamale.' I am a seller of tamale.' }
\end{aligned}
$$

APPLICATIVE

$$
\begin{aligned}
& \text { jwa-chi-s-ti=rini wichu-ni } \\
& \text { (60) bring-APPL1/2O-AOR-ASs3s=s1SG dog-OBJ } \\
& \text { 'He brought the dog to me.' 'He brought my dog to me.' } \\
& \text { xïpa-ku-a-xa-p-ka } \\
& \text { (61) steal-APPL3O-O3PL-PROG-PST-ASs1/2s } \\
& \text { 'You were stealing from them.' }
\end{aligned}
$$

A suffix of voice may coexist with a locative suffix, as in (57), in which the first -na refers to an interior area, the chest, and the second -na is the morpheme of the passive voice. Two voice morphemes may coexist when one of the two morphemes is the impersonal -na, as illustrated in (62) with the reciprocal suffix, in (63) with the reflexive suffix, and in (64) with the antipassive suffix (Capistrán 2010, Chamoreau 2009, Monzon 2004, Nava 2004).

$$
\begin{aligned}
& \text { wanti-ku-p'era-na-xïn-ti } \\
& \text { (62) kill-FT-RECP-PASs-HAB-ASs3s } \\
& \text { 'They kill each other.' }
\end{aligned}
$$




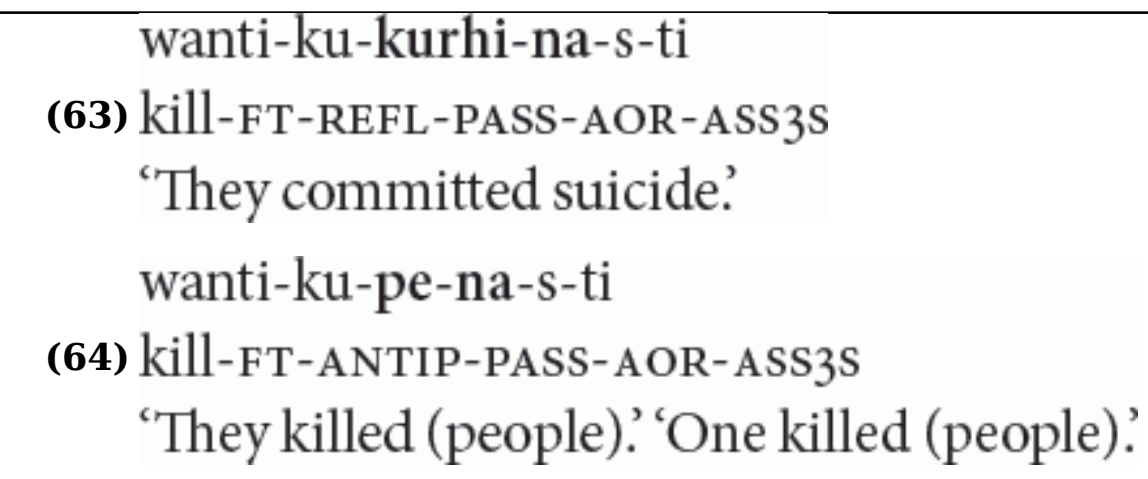

The coexistence of two applicative suffixes is also possible, but this is restricted to constructions in which the second argument corresponds to the possessor of the first, both arguments introduced by the applicative voice. This construction constitutes an external possession strategy. In it, each argument introduced by the applicative voice has its own function. It is common as a way of introducing the possessor of a body part, as illustrated in (65). In this example, the first - $k u$ codifies the fact that the body part does not belong to the subject (Section 32.4.1); the second -ku codifies the patient and corresponds to the possessed (p.690) entity (the nose of the girl); and the third -ku corresponds to the possessor, Ismaeli. In these constructions the possessor is affected by the action.

\section{(65)}
jupa-rhu-ku-ku-ku-a-ti
wash-PROJ.LONG-NCS-APPL3O-APPL3O-IRR-ASS3S
'He will wash the nose of the girl of Ismael.'
nanaka-ni
girl-oBJ

Ismaeli-ni

Ismaeli-OBJ

In example (66), the co-occurrence of the causative -ra and the two applicative morphemes results in a verb with three objects. The first applicative marker $-k u$ codifies the possessed entity, $k^{\prime}$ urhunta-ni, whereas the second applicative marker -che codifies the possessor entity, the first person object enclitic $=$ rini. This external possession construction applies to a verb that is marked by the causative marker -ra. The causer is the subject of the clause and the causee is encoded as a syntactic object in the clause, Celia-ni.

(66)
Maria=rini jwa-ra-ku-che-a-ti
k'urhunta-ni
Maria=O1SG bring-CAUS-APPL3O-APPL1/2O-IRR-ASS3S tamale-oBj
'Maria will ask Celia to bring my tamale for me.'

CeliaCelia-

To sum-up: Purepecha has a productive verbal morphology and a large number of slots in the verb, though the development of the different types of suffixes show an unbalanced treatment between locative suffixes and the other suffixes. 


\subsection{Non-Finite Clauses}

For Baker (1996), non-finite clauses should not be possible in polysynthetic languages, as the expression of the arguments must be on the verb, and agreement morphology is only possible in finite tensed verbal forms. Nevertheless, Nordlinger and Saulwick (2002) show that a canonical polysynthetic language, Rembarrnga, has two types of non-finite clauses, with and without pronominal affixes on the verb. They claim that non-finite verbs inflected by person are not uncommon: for example, they are attested in some Romance languages, such as Portuguese. Purepecha constitutes another challenge for Baker's restrictions. This language has three different types of non-finite clause: two subordinate clauses (non-finite complement clauses and purpose clauses), and a syntactic independent clause (the chain-medial clause). In these three types of clause, the verb may be marked by the third person plural object suffix. Chain-medial clauses may also include a subject enclitic attached to the verb. In Purepecha, finiteness is a clear multilayered feature including the characterization of various properties, in particular combinations of aspect, tense, irrealis, mood (ATIM), and referential continuities, and intonation contour (Chamoreau 2016). In this language, non-finite chain-medial clauses occupy an intermediate position in the finiteness continuum between two extreme positions: independent finite clauses (ATIM markers, possibility of a different referent, separate intonation contours) and non-finite complement and purpose clauses (no ATIM markers, same reference, one intonation contour).

\section{(p. 691) 32.5.1 Subordinate clauses: non-finite complement and purpose clauses}

Purepecha has two types of complement clauses: a finite complement clause with the complementizer exka (see Chamoreau 2016) and a non-finite complement clause.

In finite complement clauses, the complementizer is placed at the beginning of the complement clause, and the predicate is always modified by the mood $-k a$ called "subjunctive" (a type of marker of dependence). Tenses and aspects are present, but they have a distinctive form. In particular, aspects have a reduced form: for example, the aorist is encoded $-\chi-($ or $-s-$ ) in an independent or main clause, as in (67), and unmarked in a dependent clause. Co-reference is possible, but generally there is no co-reference between main and dependent clauses. 
(67)

juchi

nante no wé-ka-x-ti

[éxka=ni

ni-ø-ka

POSS1SG

mother NEG

want-FT-AOR-ASs3S

$\mathrm{COMP}=\mathrm{S} 1 \mathrm{SG}$

go-AOR-SBJV

ichorita-mpu]

canoe-INS

\section{'My mother did not want me to go by canoe'.}

By contrast, in non-finite complement clauses the verb is marked by the overt non-finite marker -ni, with no ATIM, no complementizer, no pronominal enclitic, generally samesubject as in (68a), and the same intonation contour. In the non-finite complement clause, there is co-reference between the agent of the main and complement clauses, as in (68a) (92.5\% of the occurrences); in the case of manipulative verbs, as in (68b), the manipulee of the main clause (syntactic object) is co-referential with the agent of the complement clause (7.5\% of the occurrences). This construction is used in order to indicate successful manipulation.

(68)
a. ero-ta-xa-ka
[k'ama-ta-ni
prontu]
hope-CAUS-PROG-ASs1/2s
finish-CAUS-NF
quickly
'I hope to finish soon.'
b. no=chk'a jwina-x-ka
ugo-ni
[jupi-ka-ni juchi
$\mathrm{NEG}=$ then allow-AOR-ASs1/2s
Hugo-овJ
take-FT-NF POssisg
'I do not allow Hugo to take my horse.'

The non-finite purpose clause is introduced by para, with co-reference and TAM continuity, as in (69). This construction is not attested in the sixteenth century and seems to be a grammatical replication of the Spanish construction: para + non-finite $V$ :

\section{Kumicho incha-parha-ku-X-p-ka \\ Ocumicho enter-LONG.EXT-NCS-AOR-PST-ASS1/2s \\ (69) [para eskwela arhi-t'a-a-ni] \\ for school say-IT-O3PL-NF \\ 'I had entered into Ocumicho in order to teach them.'}

(p. 692) In non-finite complement and purpose clauses, the verb can have its own object codified by a third person object suffix, as in (69) and (70), a pronominal enclitic, as in (71), or a noun phrase, as in (68b). 


\section{Purepecha, a Polysynthetic but Predominantly Dependent-Marking Language}

(70)
jucha=na wé-ka-xïn-ka=kxï
S1PL.IND=EV want-FT-HAB-ASs1/2S=S1
'We want to accompany them.'
wé-ka-xïn-ti=rini [ata-ni]
(71) want-FT-HAB-Ass3s=O1SG beat-NF
'He wants to beat me.'

\subsubsection{Non-finite chain-medial clauses}

Within work on discourse coherence, a clause-chain is characterized as the "smallest unit of coherent multi-propositional discourse", one that has "the tightest, most continuous cross-clausal coherence links" (Givón 2001: 355). Chain-medial clauses "carry the bulk of sequential new information in the chain, and display the highest degree of cross-clausal coherence. Their grammatical marking is the most minimal, since most threads of thematic coherence (topical referents, temporality, aspectuality, modality, perspective) remain the same" (Givón 2001: 356). Chain-initial and chain-final clauses are generally the most finite type, while chain-medial clauses are the least finite (the degree of finiteness of chain-grounding clauses is often unpredictable, although generally they are nominalized phrases). The correlation between degree of finiteness and clause-types within the chain in discourse shows that the more referential ones and those with thematic predictability-corresponding to the highest degree of cross-clausal coherence and continuity-display less finiteness.

Non-finite chain-medial clauses in Purepecha are constructions employed to facilitate thematic, referential, and aspectual continuities in discourse (Chamoreau 2016). Such strategies thus correlate with reduced finiteness. When the subject is the same in the discourse, reference tracking is always possible and easy; in a chain-medial clause the referent generally has the function of the subject. In the chain-initial clause, as in (72a), the referent is introduced by the definite noun phrase acheti-echa 'the men', and the verb is marked by aspect. In chain-medial clauses, as in (72b) and (72c), the pronominal enclitic $=k s i ̈$ is attested and attached to the verb (see also example (27)). The evidential non-pronominal enclitic $=$ na follows the pronominal enclitic (see Section 32.3.1.). Referential and tense-aspect-mood continuities are crucial to understanding the use of these constructions. In non-finite chain-medial clauses in Purepecha, ATIM are not expressed but are easily recoverable. The aspect of the narratives is generally the aorist, as in (72a). 
(72)

a. xasï=ksï=nha kustakwa jinkoni acheti-echa pa-s-ti,
next=s3PL=EV music COM man-PL
'They said that then the men took her with music,
b. ka jikwa-ra-ni=ksi=nha $\quad$ ya,
and bathe-CAUS-NF=s3PL=Ev now
and they said that they bathed her,

(p. 693)

$\begin{array}{ll}\text { c. ka ampa-tsi-ku-ni=ksï=nha } & \text { ya. } \\ \text { and be_clean-LOw-NCS-NF=s3PL=EV } & \text { now } \\ \text { and they said that they combed her.' } & \end{array}$

In short, Purepecha may be viewed as a polysynthetic language that has non-finite clauses. In the three types of non-finite clause, the suffix of the third person plural object may be suffixed and in chain-medial clauses the pronominal enclitic may be attached to the verb, as in Portuguese and as Nordlinger and Saulwick (2002) show for Rembarrnga.

\subsection{To what Extent is Purepecha Polysynthetic?}

Purepecha exhibits properties that lead us to identify it as a polysynthetic language. Even if some of the properties are generally not identified as prototypical for that type of language, the cluster constitutes an interesting correlation for a polysynthetic language:

- Morphology plays a prominent role due to the existence of a number of bound morphemes.

- Complex verb forms feature a large number of morphemes or potential slots per word.

- It allows for "word sentences', i.e. complex word forms that correspond to whole sentences in other languages.

- It accepts arguments attached to the verb, showing, in some contexts, head-marking features: when first and third persons are unmarked for subject, when the third person plural object suffix is attached to the verb, and when applicative suffixes introduce recipient, beneficiary or external possessor.

- Purepecha recently displays head attraction and pronominal enclitics may be attached to the verb, making this language more polysynthetic.

- Non-finite clauses accept arguments attached to the verb, like finite clauses. 


\title{
Purepecha, a Polysynthetic but Predominantly Dependent-Marking Language
}

Purepecha is thus a predominantly dependent-marking language (head-marking features are restricted to some contexts) in which verb forms feature a large number of morphemes per word (having developed widely locative suffixes but less other types) and that displays various types of non-finite clauses. But even with these features, Purepecha can be polysynthetic, even though it is not a prototypical polysynthetic language, unlike the Mixezoquean languages, for example.

The question to be addressed, then, is the position of Purepecha relative to other polysynthetic languages. In other words, the question is: To what extent is Purepecha polysynthetic? Drossard (1997) proposes an interesting typology that distinguishes "sentential" and "non-sentential" polysynthetic languages. In "sentential" polysynthetic languages, one word (p. 694) represents one sentence and the language displays polypersonalism and/or noun incorporation. By contrast, in "non-sentential" polysynthetic languages arguments are not attached to the verb in bound forms, but a whole range of other affixes can be attached to the verb. Purepecha is not clearly "sentential" or "nonsentential", as it shows features of both extreme types, but it is located somewhere in between these two types: a word may constitute a sentence, and one of the arguments (third person plural object) is attached to the verb, while the others may be attached to the verb (see also Mattissen 2002 for Nivkh). However, the new positions for pronominal enclitics that exhibit head attraction may locate Purepecha closer to the "sentential" type.

\section{Abbreviations}

\author{
AC \\ active \\ AOR \\ aorist \\ ANTIP \\ antipassive \\ APPL \\ applicative \\ ART \\ article \\ ASS \\ assertive \\ CAUS \\ causative \\ CENTRIF \\ centrifugal \\ CENTRIP \\ centripetal
}






Page 35 of 38

PRINTED FROM OXFORD HANDBOOKS ONLINE (www.oxfordhandbooks.com). (c) Oxford University Press, 2015. All Rights Reserved. Under the terms of the licence agreement, an individual user may print out a PDF of a single chapter of a title in Oxford Handbooks Online for personal use (for details see Privacy Policy). 


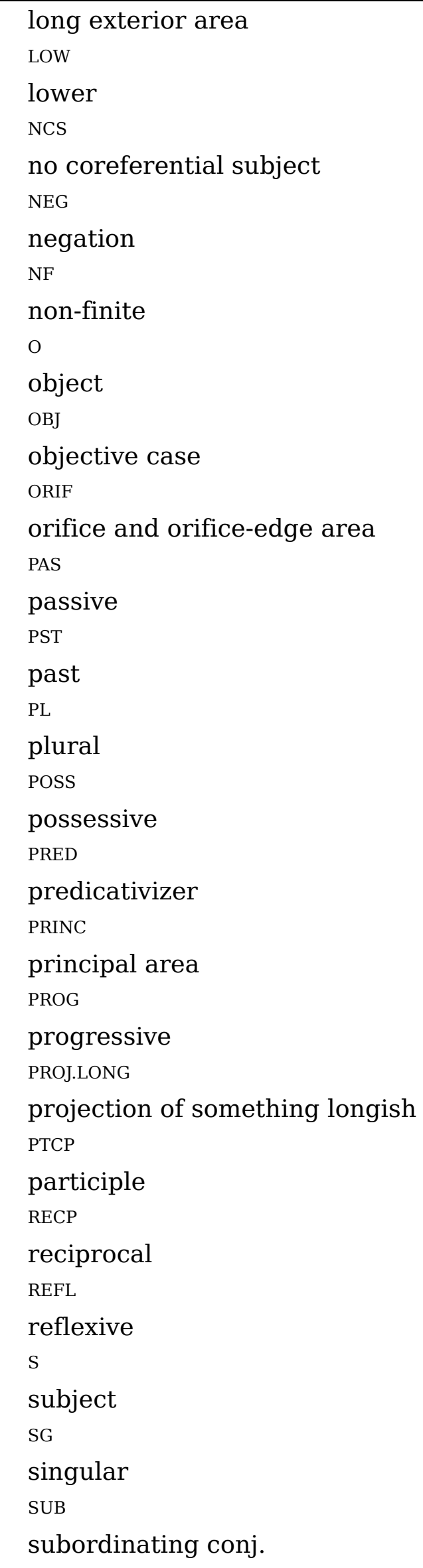




\section{Purepecha, a Polysynthetic but Predominantly Dependent-Marking Language}

SBJV

subjunctive

SUP

superior area

VERT

flat and vertical area

\section{(p. 695) Acknowledgements}

This research was made possible through financial support from the French Center for American Indigenous Language Studies, CELIA (CNRS-INALCO-IRD), the French Center for the Structure and Dynamics of Languages, SEDYL (CNRS-INALCO-IRD), and the French Center for Mexican and Central American Studies, CEMCA (CNRS-MAEE). It would not have been possible without the support of Teresa Ascencio Domínguez, Puki Lucas Hernández, Celia Tapia, and all our Purepecha hosts. I wish to thank Marianne Mithun and Roberto Zavala Maldonado for their comments on earlier versions of this paper.

\section{Notes:}

(2) The first person object enclitic $=t s^{\prime} i \ddot{n i}$, and the second person object $=k x i ̈ n i$ are always used when the subject is plural.

(1) For the first person plural, the difference between $=c h^{\prime} e$ and $=k x \ddot{i}$ (or $=k s i$ ) today exhibits a dialect variation (Chamoreau 2009: 64) that reveals a diachronic change: in the sixteenth century only $=k u c h^{\prime} e$ (the marker that has been grammaticalized in $c h^{\prime} e$ ) was used.

(3) In the singular, subject pronouns are simple forms, and in the plural, the plural marker -cha is suffixed to the singular form. Object pronouns are complex entities constituted by three elements now considered to be lexicalized, that is, subject pronoun plus objective case marker and objective pronominal enclitic (see Table 32.2), for example, in the case of the second person, $t^{\prime} u-n i=k i n i$.

\section{Claudine Chamoreau}

Claudine Chamoreau is a researcher in linguistics at the French National Centre for Scientific Research (CNRS, SEDYL-CELIA, Paris and CEMCA, Mexico). Her interest in linguistics is the description of the syntax of Amerindian languages. She has a particular interest in the complexities of Purepecha (isolate language, Mexico) and 
Purepecha, a Polysynthetic but Predominantly Dependent-Marking Language

Pesh (Chibchan family, Honduras). She also explores syntactic changes appearing in settings involving language contact and the relation between contact-induced change and internally motivated change, in particular grammaticalization.

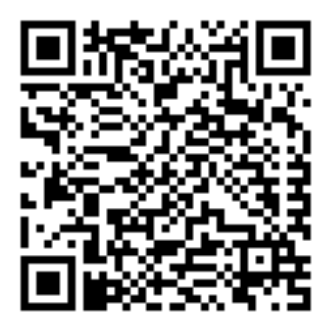

